\title{
Economic Sustainability of Pig Slaughtering Firms in the Production Chain of Denomination of Origin Hams in Italy
}

\author{
Giuseppe Bonazzi ${ }^{1}$, Paolo Camanzi ${ }^{2}$, Giovanni Ferri ${ }^{1}$, Elisa Manghi ${ }^{1}$ and Mattia Iotti $^{3, *}$ (D) \\ 1 Department of Veterinary Science, University of Parma, 43126 Parma, Italy; giuseppe.bonazzi@unipr.it (G.B.); \\ giovanni.ferri@unipr.it (G.F.); elisa.manghi@unipr.it (E.M.) \\ 2 Analisiaziendale.it Srl, 40121 Bologna, Italy; paolo.camanzi@analisiaziendale.it \\ 3 Department of Engineering and Architecture, University of Parma, 43124 Parma, Italy \\ * Correspondence: mattia.iotti@unipr.it
}

\section{check for}

updates

Citation: Bonazzi, G.; Camanzi, P.; Ferri, G.; Manghi, E.; Iotti, M. Economic Sustainability of Pig Slaughtering Firms in the Production Chain of Denomination of Origin Hams in Italy. Sustainability 2021, 13, 7639. https://doi.org/10.3390/ su13147639

Academic Editors: João Carlos de Oliveira Matias, Paolo Renna and George K. Symeon

Received: 9 May 2021

Accepted: 6 July 2021

Published: 8 July 2021

Publisher's Note: MDPI stays neutral with regard to jurisdictional claims in published maps and institutional affiliations.

Copyright: (c) 2021 by the authors. Licensee MDPI, Basel, Switzerland. This article is an open access article distributed under the terms and conditions of the Creative Commons Attribution (CC BY) license (https:// creativecommons.org/licenses/by/ $4.0 /)$.

\begin{abstract}
Pork meat in Italy is one of the largest agri-food chains in Italy. In the swine production chain, slaughter plays an important role, because it has an impact on animal welfare, food safety and the sustainability of the agri-food chain. These companies also deal with pigs destined for typical Denomination of Origin products and therefore play an important role in the production chain of typical products and in the field of EU agricultural policy. In this context, the research aims to analyze the economic sustainability of the major pig slaughter firms in Italy, through data analysis of the annual account statement (AAS) on a sample of eight companies analyzed over a ten-year historical series. Financial ratios and margins (FRM) analysis is applied in the research. FRM analysis shows that firms have the largest absorption of financial resources in the net working capital cycle. The research highlights the high incidence of raw materials in companies in the sector. Consequently, the profit margins of the companies in the sample are modest and in some cases are lower than the cost of debt, suggesting a moderate capacity to attract capital. This result appears as a negative signal of the economic sustainability of the companies in the sector. The research, now limited to a small number of large companies, opens a line of research that can be developed by expanding the sample to small and medium-sized enterprises of the chain of Denomination of Origin hams in Italy to suggest improvement interventions, in particular for rural or marginal areas of production.
\end{abstract}

Keywords: pig slaughtering; pig production chain; animal welfare; PDO and PGI products; net working capital; DuPont analysis

\section{Introduction}

The pig processing industry and its related industries characterize the Italian agri-food system. The Italian pig sector is characterized by numerous figures of operators involved both in the agricultural phase and in the subsequent industrial process of transformation. The two segments of the pig production chain in Italy are united by slaughtering activities. These companies play an important role in the sustainability of the agri-food chain, because they control the origin and quality of agri-food production in an important node of the production chain, namely the transition from the agricultural production phase to the industrial transformation phase, thus guaranteeing the traceability of production, food safety, and therefore the transparency of the consumer market [1-3].

Heavy pig breeding characterizes Italian pig farming and makes it different from that of the rest of Europe; the breeding of heavy pigs characterizes Italian production with the qualitative distinction and the link with the territory and to improve the generation of value; pig production has a major impact on consumer choices $[4,5]$. The slaughtering sector plays an important role in food traceability, guarantees food safety, and reduces the information asymmetry between producer and consumer [6]. For this reason, various actions of the Community Agricultural Policy (CAP) have been implemented in order to favor the integration of the food chain, also in the pork sector [7]. Various legislative 
interventions, at European and Italian levels, have been approved by the respective bodies of law to guarantee food safety and traceability of the pork supply chain [8]. The efficiency of the agri-food supply chains has a recognized role in generating positive externalities for food security, the maintenance of employment in rural areas, the protection of typical food products, and the role of environmental protection [9]. Among the swine slaughtering companies, there have been several cases of firm crisis in the last decade, which has led to a progressive concentration in the slaughter sector. However, firms in this sector still seem to suffer from modest profitability and difficult access to the capital market, in particular as regards the risk capital market through stock exchange listing. In fact, none of the major players in the slaughtering market is listed on the stock exchange [10].

Pig breeding in Italy [11] is mainly located in the regions of northern Italy; in particular, $50 \%$ of the animals are present in Lombardy, and overall in northern Italy (Lombardy, Piedmont, Emilia Romagna, and Veneto) there are 89\% of the animals. In 2018 [12], the national pig herd amounted to 8.5 million head, placing Italy in seventh place in Europe for size of the pig breeding. The breeding of heavy pigs destined for PDO (Protected Designation of Origin) production must comply with precise requirements of age, weight, genetic origin, and nutrition [13]; the number of pigs certified in 2018 for PDO production was 7,900,240 and represented about $70 \%$ of the domestic production, with a production of approximately 15 million hams. In the Italian territory there are 11 regions, all located in central-northern Italy, interested in the production of PDO hams [14]. The protected production system favors the production system and the economy of the territory, protects the environment, and supports the social cohesion of the entire community [15].

The European Union has created a brand system to promote and protect the denomination of quality agricultural and food products.

The Italian processing industry is strongly oriented to the production of PDO and PGI (Protected Geographical Indication) cured meats, with a strong concentration in Lombardy and Emilia Romagna. The industrial phase of the pig production chain, in particular that relating to the second transformation of meat, is a very important induction for the Italian industry in economic terms, generating a turnover of 8.08 billion euros, equal to $6 \%$ of the total turnover of the agri-food industry [16]. Ham and cured meat factories are more fragmented than the first processing establishments (slaughterhouses) and are in many cases integrated with them or constitute the downstream phase of the production chain. There are 43 quality agri-food products based on the pig, of which 21 are PDO and 22 are PGI. In 2018, certified meat-based production in Italy amounted to over 200 thousand tons, equal to a turnover of over 2 billion euros. Among the certified cured meats, Prosciutto di Parma PDO is the leading product in the sector with a production of 85,400 tons $(41.9 \%$ of the total) and a turnover of 824 million euros (40.8\% of the total).

In 2018, 11.251 million pigs were slaughtered in Italy. The slaughtering activity is concentrated in the main production areas, Lombardy and Emilia Romagna, where almost $72 \%$ of Italian slaughter is concentrated.

There are 56 slaughterhouses recognized for the slaughter of pigs for production with the denomination of origin, $82 \%$ of which are in Northern Italy, particularly in the Lombardy and Emilia Romagna regions and specifically in the provinces of Cremona, Mantova, Parma, and Modena.

The study therefore aims to analyze the economic sustainability of management in the sector; to achieve the scope of the research, a dataset of a sample of companies was analyzed, which were chosen from among the largest in Italy. The main scope of the research was the deepening of the analysis about the sustainability of the working capital cycle and the sustainability of the relationship between return on capital and cost of debt. To achieve this scope, it was necessary to analyze the data of the companies through annual account statements (AASs); appropriate ratios were applied to the AASs to make comparable financial data of the various companies included in the sample. 


\section{Materials and Methods}

\subsection{Annual Account Statement (AAS) Analysis}

The analysis of management data is used to analyze the economic sustainability of the business cycle. This data is compulsorily made available every year by companies in the AAS. The AAS is the main document for the analysis of the economic, equity, and financial analysis of the management [17]. AAS is mandatory for joint-stock firms or cooperatives. The AAS analysis designates a complex activity, carried out with the use of a body of techniques, based on codified methods for carrying out investigations on the AAS to obtain information about management and the company; the purpose is to obtain useful information for the analysis of company performance, from parties internal or external to the company itself according to selected schemes. The AAS analysis provides the tools to implement assessments of management results, and consequently it is one of the most effective tools for diagnosing the health of a company; however, being based on final data, it often turns out to be untimely (in the case of analysis of "historical" data).

AAS quantifies the annual results of management followed by the accrual principle, which is the change in the value of equity given by the shareholders of the company due to management. In Europe, the annual account is the main accounting record of disclosure and is mandatory in Italy for companies and cooperatives (according to the provision of Article 2423 and following of the Italian Civil Code, the annual account consists of the balance sheet, income statement and integer notes, acknowledged as the D. Lgs. 127/91, which applies to the Fourth Council Directive, EU Directive 78/660/EEC IV, of 25 July 1978). The AAS account is formed by a balance sheet statement (BSS) and an income statement (IS), which are mandatory documents [18].

In the BSS, activities are classified by the method of increasing liquidity and decreasing liabilities, as investment and source of capital, i.e., a financial-based approach. The reclassification allows the comparison of investment (short and long-term) and loans (at the same time, short and long-term), assessing the ability, with a balance of structural and short term, to meet the financial needs of the company. The degree of liquidity of a BBS item should express its ability to turn into currency within a range before the end of the reporting period. The degree of liquidity expresses the ability of the assets to become liquid cash in a given time, more or less one year. The general equation of the balance sheet, reclassifying data from the AASs on liquidity and due date of debts (i.e., according to financial criteria), is shown in Table 1.

Table 1. Reclassified balance sheet (BS) with financial-based approach.

\begin{tabular}{l}
\hline L-Liquidity (cash and bank) \\
\hline WCii-Working Capital investment. Inventories \\
WCari-Working Capital investment. Accounts receivable \\
WCoi-Working Capital investment. Others \\
\hline WCiT-Working Capital Investment. Total \\
\hline FA-Fixed Asset \\
\hline TA-Total Asset \\
\hline WCaps-Capital source. Accounts payable \\
WCos-Working Capital source. Others \\
FDM < 12-Financial debts. Due less than 12 months \\
\hline DM $<12$-Short Term Debts. Due less than 12 months \\
\hline FDM $>12-$ Financial Debts. Due more than 12 months \\
\hline DT-Total Debt
\end{tabular}


Table 1. Cont.

\begin{tabular}{l}
\hline Esc-Equity. Share capital \\
Er-Equity. Reserves \\
EpT-Equity. Post taxes profit \\
\hline ET-Total Equity \\
\hline TS-Total Source \\
\hline
\end{tabular}

As seen in Table 1, in a given year of analysis, investments are composed of FAs (fixed assets), WCii (working capital assets, inventories of stock), WCari (working capital assets, accounts receivable), WCoi (working capital assets, other assets), and L (liquidity), and the sources are given by Esc (share capital), Er (reserves), ПpT (profit after taxes), WCaps (working capital liabilities, accounts payable), WCos (working capital liabilities, other values), FDM < 12 (debt due within 12 months), and FDM > 12 (borrowings due after 12 months). For the generic period, $t$, is the total assets (TA) as the total of the invested capital, while TS is the source of capital, calculated as the sum of equity capital ET = Esc + $\mathrm{Er}+$ ПрT, and debt capital DT $=$ WCaps + WCos + FDM $<12+$ FDM $>12$, where WCaps + WCos $+\mathrm{FDM}<12=\mathrm{DM}<12$ is short term debts. TA is total assets (total capital investment), and TS is total source (source of total capital). The sum WCiT-Wcaps-Wcos is called net working capital (NWC), and for the majority of companies [19], the cycle of payments and receipts, resulting from the net working capital is shorter than the cycle given by the outflow of money for investments and its return. NWC analysis is used to assess the economic sustainability of the short-term payment cycle; NWC analysis is often applied for the predictive analysis of the business crisis. Some studies show [20-22] an inverse relationship between NWC and profitability. NWC expresses the amount of net resources generated $(\mathrm{NWC}<0)$ or absorbed $(\mathrm{NWC}>0)$ by the management of the working capital cycle [23]. If NWC $>0$ there is a conservative or prudent working capital management policy [24]. Several studies [25] show that if it emerges that the conversion into currency of the values generates a monetary quantity greater in absolute value than that necessary for the payment of the financial commitments, the situation whereby $\mathrm{NWC}<0$ is defined as aggressive working capital management policy [26], this situation is to be considered at risk, it having been shown [27] that NWC $>0$ is inversely correlated to financial distress. Working capital management has been shown to be particularly relevant for small businesses [28,29]; these firms have limited access to the medium/long-term financing capital market and tend to finance investments with debt maturation within 12 months and show higher failure rates than large firms $[30,31]$. Therefore, the management of working capital has effects on the survival and growth of businesses, particularly small ones [32-35] Recent studies have indicated the relationship between net working capital and enterprise performance, both in the case of SMEs [36] and in the case of large food enterprises [37]. The results suggest that firms with available cash flow should increase investment in working capital to improve performance. There is therefore a direct relationship between investments in NWC and the performance of companies, even if the increase in NWC requires sources of financing that not all companies are able to raise on the capital market. Several studies have also been conducted on the sustainability of the NWC cycle in relation to the life cycle of the company [38] and highlighted that successful companies must change their working capital management strategy according to the sector they belong to and according to the phase of the life cycle. The research therefore aims to analyze the absorption of net working capital of pig slaughtering companies in Italy, which are characterized by collection times of trade receivables longer than the time of payment of trade payables. On this topic, various studies have been carried out in the food sector [39], in the fishing sector [40], and in the sector of cheese processing [41]. On this research topic, there are no studies for the swine slaughter sector.

To carry out the research, it is also necessary to analyze the income performance of companies; for this analysis, income statements (ISs) are analyzed. The reclassification 
of ISs is based on the criterion of value added that allows one to use only information available in the scheme from the annual account. The information is readily available from the documents of the annual account; this type of IS reclassification, which adopts a classification by type of positive and negative components of income, is therefore also analyzed by the external reader of the annual account, such as banks, and allow one to highlight the wealth actually produced and distributed by the various contributions of inputs (labor, materials, capital, and the state). In particular, the distinctive feature of this approach is the ability to highlight a number of relevant intermediate results, such as production value, net consumption, value added, and various operating margins, as seen in Table 2. The application of the analysis of the IS was performed by some research for the pig production sector [42], but not for the slaughter phase. IS analysis is used to verify economic sustainability from the point of view of income generation and also considering the ability to pay the cost of debt.

Table 2. Reclassified income statement (IS) with value added-based approach.

\begin{tabular}{l}
\hline$(+)$ S-Sales \\
\hline$(+/-) \Delta$ I-Change in inventory value \\
$(+)$ OR-Other revenue \\
\hline$(+/-)$ VP-Value of Production \\
\hline$(-)$ M - Raw materials cost \\
$(-)$ S-Services cost \\
$(-)$ R-Rent cost \\
$(-)$ OC-Other costs \\
\hline$(+/-)$ VA-Value Added \\
\hline$(-)$ L-Labor cost \\
\hline$(+/-)$ EBITDA-Earnings before interest, tax, depreciations, and amortizations \\
\hline$(-)$ D-Depreciations \\
$(-)$ A-Amortizations \\
\hline$(+/-)$ EBIT-Earnings before interest and tax \\
\hline (-) IC-Interest charge \\
$(+)$ IR-Interest revenue \\
$(+/-)$ SF-Net Interest \\
$(+/-)$ W-Revaluations and Devaluations \\
$(+/-)$ X-Extraordinary revenues and costs \\
\hline$(+/-)$ ПaT-Profit before taxes \\
\hline$(-)$ T-Income taxes \\
\hline$(+/-)$ ПpT-Profit after taxes
\end{tabular}

In a generic company and in a given period, IS quantifies the profit generated from the management to the shareholders. In Table 2, VP is the value of production, M is raw material purchases, $\mathrm{S}$ is purchases of services, $\mathrm{R}$ is charges for use of third party assets, $\mathrm{OC}$ is other operating costs, and L is the cost of labor; thus, EBITDA (earnings before interest, tax, depreciations, and amortizations) is an intermediate income margin that is used to estimate the creation of liquidity, being net of non-monetary costs (D + A); EBIT (earnings before interest and tax) is the profitability margin that expresses the operative income; SF is the balance of financial management as the algebraic sum of interest charge (IC) and interest revenue (IR); $\mathrm{W}$ is the balance of revaluation and impairment of financial assets; $\mathrm{X}$ is the balance of extraordinary income and expenses; $\mathrm{T}$ are income taxes; and $\Pi p \mathrm{~T}$ is profit after taxes. The value of production (VP) is the sum of sales (S), the change in value of inventories $(\Delta \mathrm{I})$, and other revenues $(\mathrm{OR})$. Applying the algebraic sum to the results of different management areas (and thus obtaining intermediate profit margins), the result is the profit (or loss) for the year. 


\subsection{Financial Ratios and Margins (FRM) Analysis}

The financial ratios and margins (FRM) analysis is widely used in the analysis of the performance and the risk of firms' management [43-49]. Starting from AAS data, the financial ratios and margins (FRM) analysis is based on the accrual basis [50]. Ratios and margins are identified and used in the analysis as they can provide information on financial performance (profitability), as well as patrimonial and financial aspects of firm management. For the purposes of internal and of external analysis, to have expressive indicators of firms ${ }^{\prime}$ managements (and by extension, investments), the applied ratio and margins analysis aggregates (in relationships or differences) the values of the annual account. Several studies in recent years apply the FRM analysis, using the DuPont chart approach, to the analysis of the performance of companies, in various economic sectors [51-53]. In our research, data analysis was carried out by checking the main aspects of business management, through the use of ratios and margins calculated based on the data contained in the AAS for credit scoring in the specific case of agri-food firms [54-56]. Although several studies have been developed on the economic sustainability of the slaughtering sector $[57,58]$, no study has so far applied the FRM analysis to swine slaughter companies.

In the research we applied the FRM to analyze (a) profitability, (b) solidity of the capital structure, (c) liquidity, and (d) duration of the cash conversion cycle. The profitability analysis quantifies the ability of operating margins to remunerate the capital invested to finance investments. The main measure of profitability is the ROE (return on equity), which aims to quantify the return on share capital; ROE is expressed as a nominal return on equity capital during the financial year and is expressed as the ratio between profit after taxes $(\Pi p T)$ and total equity (ET) as follows: ROE $=\Pi p T: E T$. The ratio that is applied to calculate the return on capital invested in the business is the return on asset (ROA), which compares the operating income with the total capital invested. ROA is the ratio between the earnings before interest and tax (EBIT) and the total asset (TA), as follows: ROA = EBIT:TA. ROA expresses the annual rate of return for each unit of invested capital; the ROA is compared with the cost of debt to verify the effect of financial leverage, i.e., the company's ability to generate a higher profitability than the cost of debt expressed by the return on debts (ROD), where ROD = IC:FD, where IC is interest charge and FD is financial debts due in less than 12 months (FDM $<12$-Financial debts) plus financial debts due in more than 12 months (FDM > 12-FINANCIAL DEBTS).

The solidity of a firm's capital structure is then analyzed through the composition of liabilities (sources of capital) with the debt equity ratio (DER), calculated as the ratio of total debt (DT) and equity (ET), as follows: DER = DT:ET; DER expresses the level of indebtedness and it is frequently used to quantify the solidity of the capital structure in applications of scoring systems.

Liquidity analysis aims to analyze short-term financial equilibrium. The ratios applied in the liquidity analysis therefore compare the investments, which are expected to be converted into cash in the next 12 months, with the financial commitments maturing in the next 12 months. In the liquidity analysis is frequently applied the current liquidity ratio (CR), calculated as the ratio of short-term activities and liabilities, as follows: $C R$ $=(\mathrm{L}$-liquidity + WCiT—working capital investment $): \mathrm{DM}<12$-Short Term Debts; $\mathrm{CR}$ expresses the firm's capacity to cover financial obligations due within 12 months with the conversion of the assets payable within 12 months.

Finally, to quantify the duration (in days) of the cash conversion cycle, in days, are applied three main financial ratios: (1) AR_DAYS, calculated as follows: AR_DAYS = (WCari-Working Capital investment-Accounts receivable) $\times$ 365: S-Sales; AR_DAYS expresses the length of the payment deferral given to customers; (2) AP_DAYS, calculated as follows: AP_DAYS $=($ WCaps-Working Capital source. Accounts payable $) \times 365$ : SSales; AP_DAYS expresses the length of the payment given by suppliers; and (3) INV_DAYS, calculated as follows: INV_DAYS $=$ WCii-Working Capital investment. Inventories $\times 365$ : S-Sales; INV_DAYS expresses the length of inventory rotation. AR_DAYS + INV_DAYS - AP_DAYS = NWC_DAYS, where NWC_DAYS is the length of the net working capital 
(NWC) in days. An increase in AR_DAYS and INV_DAYS, and a decrease in AP_DAYS cause an increase in the capital requirement in terms of equity or debt. This situation is particularly relevant for small and medium-sized enterprises, where an increase in the value of NWC determines the need for financial coverage, to be carried out with equity or debt capital $[59,60]$; in the first case it is necessary to assess whether the entrepreneur's contribution can obtain a return at least equal to the opportunity cost of capital employment (cost of equity), given the risk profile, while in the second case it is necessary to assess whether the debt capital can obtain a return higher than its cost, through the so-called leverage effect. The expansion of the use of capital in NWC therefore always involves an increase in the use of capital, which must obtain remuneration and, in the case of debt capital, also coverage of the debt service [61]. Several studies have applied FRM to the assessment of bank-business relationships, in particular to the capacity of companies to pay the cost of debt [62]. Some researchers have applied FRM analysis to the agri-food sector to provide a means of disaggregating components of operating profitability [63] and to make available a tool for analyzing and interpreting company profitability [64], even in Italy [65]; however, the FRM analysis has never been applied to the pig slaughtering sector in Italy.

Some care must be taken when using FRM to analyze the performance of firms; in fact, (a) the balance sheet indices use economic and equity values whose quantification is influenced by the legal provisions relating to accounting; the principle of prudence determines a potential underestimation of income, at least in the short term, and does not allow one to have evidence of latent capital gains on fixed assets, as well as the accounting of the values of intangible assets; (b) the income-based AAS ratios do not consider the moment in which the financial flows occur; the evaluation with an economic approach may not highlight the lack of liquidity and, therefore, the ability of the company to meet its financial obligations; (c) the comparison between continuous (in the numerator) and punctual (in the denominator) values can result in estimation of errors of the index value (for example with respect to the average of the value during the year).

\section{Results}

\subsection{The Sample of Companies Operating in the Pig Slaughtering Sector}

In order to verify the economic sustainability trends in the pig slaughtering sector destined for the production of PDO hams, the first eight companies were selected in terms of turnover volume, analyzing the main economic and financial data and AASs for the 2008-2017 horizon, based on our processing starting from the contents of the Aida (Computerized analysis of Italian companies) database by Bureau van Dijk (Table 3).

Table 3. Dimensional data for the 2017 financial year of the eight main firms in the sector.

\begin{tabular}{ccccc}
\hline Firm & Province & $\begin{array}{c}\text { Invested } \\
\text { Capital }(\boldsymbol{(})\end{array}$ & Sales $(\boldsymbol{\ell})$ & Employees $(\boldsymbol{n})$ \\
\hline Annoni spa & Parma & $43,920,233$ & $187,426,516$ & 108 \\
CLAI scarl $\left(^{*}\right)$ & Bologna & $197,421,333$ & $261,123,955$ & 479 \\
Ghinzelli srl & Mantova & $45,439,644$ & $244,370,273$ & 115 \\
Martelli spa & Mantova & $100,972,494$ & $260,036,201$ & 145 \\
OPAS sca $(* *)$ & Modena & $69,578,656$ & $325,048,643$ & 73 \\
Pini Italia srl & Cremona & $54,355,911$ & $235,584,323$ & 140 \\
Prosus sca & Cremona & $132,271,938$ & $300,599,161$ & 230 \\
Sassi spa & Parma & $60,980,949$ & $174,083,128$ & 65 \\
\hline Total & $704,941,158$ & $1,988,272,200$ & 1355 \\
\hline${ }^{*}$ Cooperativa Lavoratori Agricoli Imolesi (Agricultural Cooperative of Workers Imola); $\left.{ }^{* *}\right)$ Organizzazione \\
Prodotto Allevatori Suini (Pig Breeders Product Organization).
\end{tabular}

As a selection criterion, the sample included companies that operate exclusively in the slaughtering sector and with a turnover exceeding 100 million euros and for which a 10-year series of data was available; the eight companies in the sample were then considered, 
satisfying the sample selection criteria. These are large companies which, due to the volume of activity and the number of employees, represent some of the largest companies in the pork food chain. Of the eight companies under consideration, three are cooperative companies (of which two are agricultural cooperative companies), three are joint stock companies, and two are limited liability companies; four companies are located in Emilia Romagna (in the provinces of Bologna, Modena, and Parma), and four companies are located in Lombardy (in the provinces of Cremona and Mantova). For all companies, the administrative period runs from 1 January to 31 December of each year. In addition, during the delicate phase of interpretation of the results, it is necessary to consider that the aggregates are also constructed with amounts referring to cooperative companies, for which some aspects of business management have specific peculiarities; it is sufficient to remember that the analysis of profitability is typical of for profit companies and not of companies that pursue a mutualistic purpose. Finally, it should be remembered that the horizon analyzed presents the initial phase of the greatest economic crisis of the last decades as the starting point. Italy, although affected by the financial crisis to a limited extent, suffered a severe recession $(-5.2 \%)$ both due to the drop in foreign demand and the unresolved structural problems (it was the industrialized country with the worst performance in the three-year period 2008-2010).

The first result of the analysis, which emerged from the financial statements of the companies in the sample, is the increase in investments. The total capital invested in the business activity by the eight selected companies stood, for the 2017 financial year, at 705 million euros, presenting an increasing trend during the 2008-2017 decade, with a significant positive change compared to the capital invested in the 2008 financial year; in fact, the total invested capital went from 462 million euros for the 2008 financial year to 705 million euros, with a difference on a ten-year basis of $52.74 \%$ and a compound annual growth rate (CAGR) of $4.82 \%$. Compared with total capital invested by the eight companies for the 2017 financial year amounting to 705 million euro, the shareholders' equity stood at 267 million euro, from which company capitalization (quotient between equity and invested capital) was equal to $37.93 \%$, a significant value, although slightly down compared to the figure for 2008 , which stood at $38.97 \%$. Since this is an indicator particularly connected to the risk of default, it should be noted that for 2017, the company capitalization for the individual companies included in the selected sample varied from a minimum of $4.76 \%$ at a maximum of $82.25 \%$; in both cases, these are companies set up as a cooperative company; it should also be noted that the two companies mentioned above were also the two extremes of capitalization in 2008: from a minimum of $2.13 \%$ to a maximum of $73.66 \%$. The aggregate sales revenues of the eight companies belonging to the selected sample showed an overall increasing trend in the decade 2008-2017, with a consistent positive change; in fact, the turnover went from 1.07 billion euros for the financial year 2008 to 1.99 billion euros, with an increase on a ten-year basis of $85.76 \%$ and a CAGR of $7.12 \%$; in view of the above, the main profit and loss margins showed an overall contrasting trend in the three-year period analyzed with regard to absolute values and an overall contrasting trend also with regard to relative values (i.e., their weight on turnover); in any case, the aggregate amounts of both the gross operating margin, and the operating result, and finally the net result at the end of the horizon under examination (2017 financial year) was greater than those relating to the beginning of the horizon analyzed (2008 financial year). During the entire period examined, the aggregate gross operating margin and the aggregate operating result always showed amounts greater than zero, while the aggregate net result presented only one case of a negative amount: aggregate final net loss of 9.5 million euros for 2012 (in that year, a cooperative and two limited liability companies closed, at a loss, one of which was over 16 million euros). We note a contrasted trend in the cost of labor per employee, which went from 44,876 euros referring to the 2008 aggregate (minimum value of the decade), to 63,939 euros referring to the 2015 aggregate (maximum value of the decade), to reach 50,312 euros in the 2017 aggregate; in the face of this trend, there was a more than proportional growth in the value of the characteristic 
production generated on average by each employee, which went from 911,448 euros referring to the 2008 aggregate to 1,471,941 euros referring to the 2017 aggregate, after reaching 1,581,796 euros in the 2014 aggregate (maximum value of the decade).

The net financial position, relating to aggregate BSS, showed a contrasting trend over the horizon analyzed, also characterized by always negative values, which means that financial payables were always greater than cash and securities in the portfolio; in detail, the net financial position went from -132 million euros for the 2008 aggregate year to -162 million euros for the 2011 aggregate year (worst value of the decade), subsequently improving to -78 million euros in the 2013 aggregate year (best value of the decade), to stand at -116 million euros relating to the 2017 aggregate year being considered, which improved the overall composition of the net financial position in the decade analyzed, given that the net financial position referring to the 2008 aggregate financial year consisted of $58 \%$ of short-term financial position and the remaining $42 \%$ of medium-financial position long-term, while the net financial position referring to the 2017 aggregate financial year consisted of $38 \%$ of the short-term financial position and the remaining $62 \%$ of the medium long-term financial position.

The VPA-Score can be applied to the data of the aggregated AASs, which is an AAS scoring model that provides a quantitative assessment concerning the performances recorded in certain management areas, with a greater weight associated with the quotient between the net financial position and the operating gross margin. The VPA-Score highlights a situation of substantial overall balance, positioning itself on an overall assessment equal to "BBB" (which corresponds to an "acceptable" risk) in 2008, touching the minimum overall assessment equal to "BB" (which corresponds to an "acceptable with attention" risk) in 2011, to finally reach the maximum overall rating of "BBB+" (which corresponds to an "acceptable" risk) in the last three years of the horizon analyzed. It should be remembered that the VPA-Score does not constitute a rating assignment, nor an AAS certification, nor an investment solicitation. Considering the VPA-Score as an acceptable proxy of corporate risk, using the data relating to the VPA-Score and those relating to the ROE, which measures the profitability of the capital employed by the shareholders, without prejudice to when indicated above regarding the profitability in companies that pursue mutual and non-profit purposes, it is possible to build a risk-return matrix, positioning the profitability of the capital employed by the shareholders on the horizontal axis (the higher it is, the better it is, allowing the members high returns on their invested capital in the company) and on the vertical axis the VPA-Score (the higher it is, the better it is, given that the business risk is low and consequently the reliability standing is high).The matrix (Figure 1) in question is presented on the basis of the AASs referring to the last financial year of the horizon in question (2017).

The purpose of the matrix is to highlight the different positioning of the companies examined, considering at the same time their performance relating to both business risk and the return in favor of ownership; the matrix is structured in such a way as to accommodate in the top right corner the companies that stand out for a high level of VPA-Score (and consequently, a low corporate risk) and a high return in favor of the property, while in the top at the bottom left are the companies that are characterized by a low VPA-Score level (and consequently a high corporate risk) and a low return on the capital invested by the property; different colors are also used for the individual points indicated in the matrix in relation to the changes recorded in the parameters compared to 2016.

Based on the analyzes carried out, there was a positive trend in the economic, equity, and financial situation of the aggregate of the eight companies during the decade under investigation; in fact, they improved the liquidity, profitability, and average duration of company operating processes; in addition, the cumulative cash flow for the period 2008-2017 was positive, and the scoring was also improving; the only data in contrast to the trend were those of company capitalization, which were slightly down in the decade but which were still positioned at considerable values, and of the returns on investment, which decreased in 2017 compared to the figure of 2008, but also in this case we can talk 
about a slight decrease, considering that the value of 2017 (2.75\%) was slightly lower than that of $2008(3.19 \%)$.

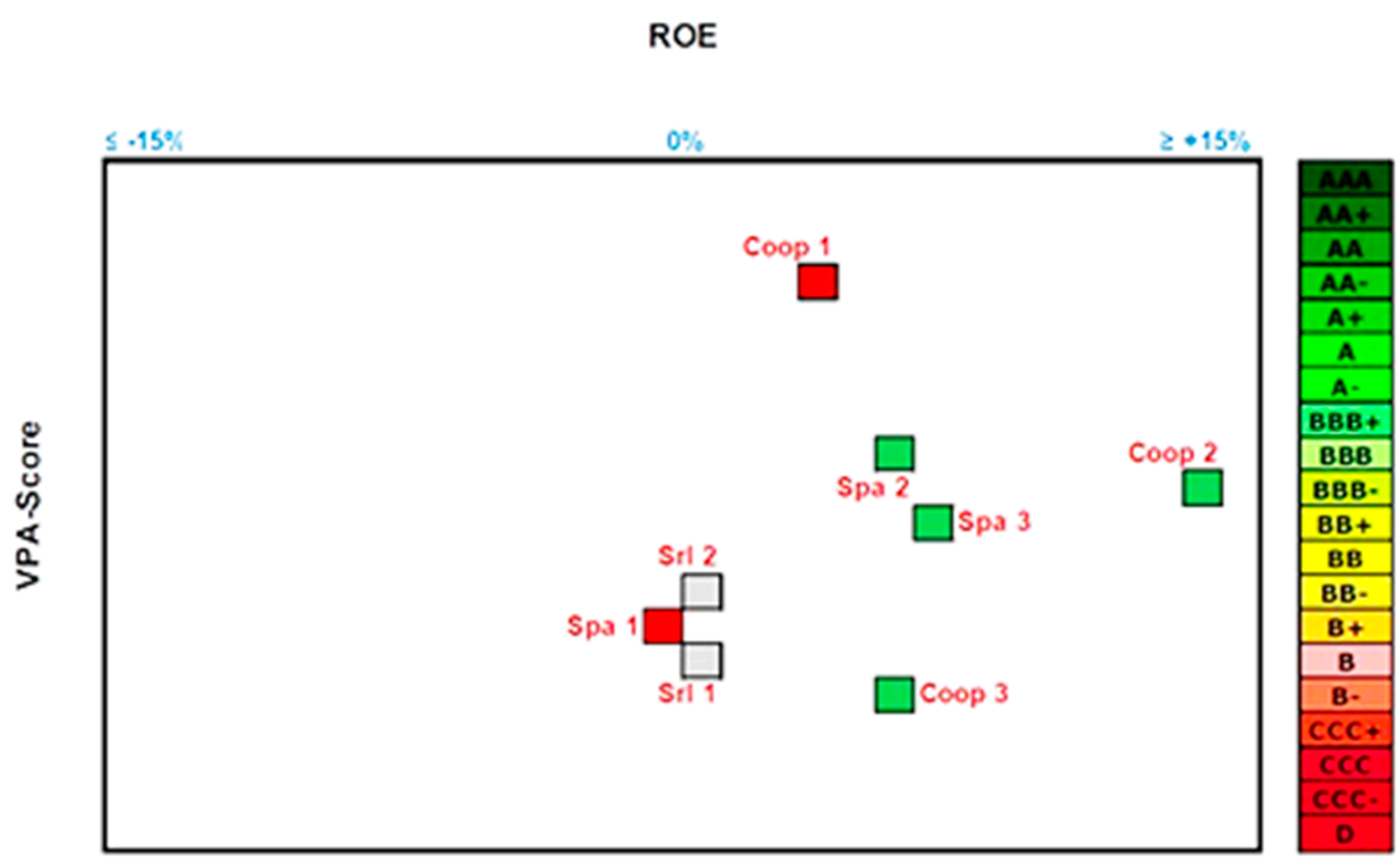

Figure 1. VPA-Score/ROE matrix. Green Box: both the VPA score and the ROE improved compared to the previous year. Red Box: both the VPA score and the ROE worsened compared to the previous year. Gray Box: all other cases.

\subsection{Analysis of the Management of the Companies in the Sample by Applying Financial Ratios and Margins (FRM) Analysis}

The typical business management characteristics of the companies in the sample were analyzed through the AAS data. The data series analyzed includes 80 observations from eight companies over a 10-year series. Table 4 shows the data relating to the balance sheet statement. It emerges that the average invested capital was around 71 million euros per company, with a median value of around 59 million. It is interesting to note that $74.91 \%$ of investments were concentrated in working capital investments, and $47.97 \%$ of investments were accounts receivable. Therefore, a considerable exposure of these companies to customers emerged, whose financial exposure represented about half of the invested assets. On the other hand, fixed asset investments represented only about $21 \%$ of investments. The structure of the sources of financing shows that the sources structurally serving the invested assets were prevalent. In fact, equity capital represented approximately $38 \%$ of the sources of financing and medium and long-term debts, over 12 months, a further $11 \%$ of the sources of financing. Therefore, the investments in the fixed assets were covered with long term sources of capital. These data were confirmed by the mean and median values, even if there was a high standard deviation, of around 32 million euros, as regards the working capital investment. Short-term debt therefore represented approximately $51 \%$ of funding sources and was divided into $21.17 \%$ of trade payables and $23.63 \%$ of financial payables, in addition to $6.27 \%$ of other short-term payables. Short-term payables were, in any case, lower than the working capital investment, which was therefore also financed with medium- and long-term sources of capital. 
Table 4. Reclassified balance sheet, 80 observation data points ( 8 firms for 10 financial years), descriptive statistics.

\begin{tabular}{|c|c|c|c|c|c|}
\hline Balance Sheet ID & Total Obs. (€) & Total (\%) & Mean & Median & St. Dev. Sample \\
\hline L-Liquidity (cash and bank) & $224,305,967$ & 3.94 & $2,803,825$ & 760,680 & $4,330,593$ \\
\hline $\begin{array}{l}\text { WCii-Working Capital } \\
\text { investment Inventories }\end{array}$ & $948,912,796$ & 16.65 & $11,861,410$ & $10,319,294$ & $10,181,414$ \\
\hline $\begin{array}{l}\text { WCari-Working Capital } \\
\text { investment Accounts rec. }\end{array}$ & $2,733,958.97$ & 47.97 & $34,174,487$ & $36,478,400$ & $14,779,785$ \\
\hline $\begin{array}{l}\text { WCoi-Working Capital } \\
\text { investment. Others }\end{array}$ & $586,567,987$ & 10.29 & $7,332,100$ & 55,766 & $19,318,187$ \\
\hline $\begin{array}{l}\text { WCiT_-Working Capital } \\
\text { Investment Total }\end{array}$ & $4,269,439,755$ & 74.91 & $53,367,997$ & $45,103,646$ & $32,357,020$ \\
\hline FA-Fixed Asset & $1,205,705,361$ & 21.15 & $15,071,317$ & $8,875,441$ & $13,573,656$ \\
\hline TA-Total Asset & $5,699,451,083$ & 100 & $71,243,139$ & $59,381,939$ & $47,205,485$ \\
\hline $\begin{array}{l}\text { WCaps-Working Capital } \\
\text { source Accounts payable }\end{array}$ & $1,206,318,846$ & 21.17 & $15,078,986$ & $13,203,700$ & $10,038,879$ \\
\hline $\begin{array}{c}\text { WCos-Working Capital } \\
\text { source Others }\end{array}$ & $357,246,011$ & 6.27 & $4,465,575$ & $3,429,394$ & $3,177,573$ \\
\hline $\begin{array}{c}\text { FDM }<12 \text {-Financial debts } \\
\text { Due less than } 12 \text { months }\end{array}$ & $1,346,715,756$ & 23.63 & $16,833,947$ & $13,872,900$ & $15,453,081$ \\
\hline $\begin{array}{l}\mathrm{DM}<12 \text {-Short Term Debts } \\
\text { Due less than } 12 \text { months }\end{array}$ & $2,910,280,613$ & 51.06 & $36,378,508$ & $33,544,002$ & $21,426,629$ \\
\hline $\begin{array}{l}\text { FDM }>12 \text {-Financial Debts } \\
\text { Due more than } 12 \text { months }\end{array}$ & $629,566,473$ & 11.05 & $7,869,581$ & $2,757,193$ & $10,342,683$ \\
\hline DT-Total Debt & $3,539,847,086$ & 62.11 & $44,248,089$ & $40,609,395$ & $25,275,032$ \\
\hline Esc-Equity Share capital & $469,678,437$ & 8.24 & $5,870,980$ & $4,710,716$ & $5,312,647$ \\
\hline Er-Equity Reserves & $1,630,868,435$ & 28.61 & $20,385,855$ & $8,156,385$ & $37,794,895$ \\
\hline EpT-Equity Post taxes profit & $59,057,125$ & 1.04 & 738,214 & 156,856 & $3,279,343$ \\
\hline ET_-Total Equity & $2,159,603,997$ & 37.89 & $26,995,050$ & $13,056,962$ & $40,630,457$ \\
\hline TS-Total Source & $5,699,451,083$ & 100 & $71,243,139$ & $59,381,939$ & $47,205,485$ \\
\hline
\end{tabular}

If the data of the equity structure did not highlight risk elements in the average of the observations made, there were criticalities in the income data shown in Table 5, which derived from the analysis of the income statement of the dataset of observations. The data of the 80 observations carried out showed a considerable average size of companies, with an average sales value of approximately 173 million euros per year. It immediately emerged that the greatest incidence among costs was given by raw materials, which accounted for $85.25 \%$ of turnover. It therefore immediately appears that it is necessary for companies in this sector to implement forms of integration of the supply chain that allow a stabilization of the purchase costs of pigs in order to be able to cope with fluctuations on the supply markets. Services also had a significant impact, with a percentage of $9.10 \%$ of the total value of sales. Among these, the analysis of the data of the income statements showed the importance of the costs for the utilities of the plants and disposal and for work on behalf of third parties; however, these data were not indicated for most of the annual account statements analyzed, and therefore it was not possible to draw definitive conclusions. However, a low profitability of the sector on average was certainly evident. In fact, the EBITDA margin, which approximates the liquidity generated by management, was equal to $1.77 \%$ of sales, with a very low value, both for the average and for the median data. The operating profitability, given by EBIT, was also low, equal to $0.96 \%$ of sales. These data, also considering the high invested capital, were reflected in low profitability financial ratios that highlight management difficulties. The cost of debt was $0.25 \%$ of sales; therefore, with a modest impact in reducing average profitability in the sample, despite this, the profit after taxes was only equal to $0.43 \%$ of sales. The analysis shows that the companies observed in the sample, even if large and operating in a concentrated sector, were not able to generate profit margins to adequately remunerate the investments made. As regards the number of observations, EBITDA was positive in 72 observations out of 80, EBIT in 69 observations out of 80 , and profit after taxes in 65 observations out of 80 . 
Table 5. Reclassified income statement, 80 observations data ( 8 firms for 10 financial years), descriptive statistics.

\begin{tabular}{|c|c|c|c|c|c|}
\hline Income Statement ID & Total Obs. (€) & Total (\%) & Mean & Median & St. Dev. Sample \\
\hline (+) S-Sales & $13,850,325,244$ & 100 & $173,129,066$ & $181,275,293$ & $70,653,237$ \\
\hline $\begin{array}{l}(+/-) \Delta \mathrm{I}-\text { Change in } \\
\text { inventories value }\end{array}$ & $62,429,804$ & 0.45 & 780,373 & $x^{2}$ & $2,961,843$ \\
\hline (+) OR-Others revenue & $25,900,710$ & 0.19 & 323,759 & 208,354 & 292,260 \\
\hline $\begin{array}{c}(+/-) \mathrm{VP}-\text { Value of } \\
\text { Production }\end{array}$ & $13,938,655,758$ & 100.64 & $174,233,197$ & $183,309,034$ & $71,234,513$ \\
\hline (-) $\mathrm{M}-$ Raw materials & $11,807,485,701$ & 85.25 & $147,593,571$ & $150,029,050$ & $58,349,647$ \\
\hline (-) S-Services & $1,260,839,577$ & 9.1 & $15,760,495$ & $16,818,128$ & $8,559,394$ \\
\hline$(-) \mathrm{R}-$ Rent & $9,761,163$ & 0.07 & 122,015 & 32,545 & 177,410 \\
\hline$(-)$ OC-Others cost & $24,532,150$ & 0.18 & 306,652 & 280,619 & 244,673 \\
\hline$(+/-)$ VA-Value Added & $836,037,167$ & $6.04-$ & $10,450,465$ & $6,875,995$ & $8,405,623$ \\
\hline$(-)$ L-Labor cost & $590,535,225$ & 4.26 & $7,381,690$ & $6,345,060$ & $5,304,456$ \\
\hline$(+/-)$ EBITDA & $245,501,942$ & 1.77 & $3,068,774$ & $1,826,754$ & $3,396,122$ \\
\hline (-) D-Depreciations & $3,116,433$ & 0.02 & 38,955 & - & 107,263 \\
\hline (-) A-Amortizations & $108,883,364$ & 0.79 & $1,361,042$ & 817,631 & $1,313,868$ \\
\hline$(+/-)$ EBIT & $133,502,145$ & 0.96 & $1,668,777$ & $1,085,194$ & $2,314,823$ \\
\hline (-) IC-Interest charge & $-59,218,010$ & -0.43 & $-740,225$ & $-600,372$ & 643,402 \\
\hline (+) IR-Interest revenue & $24,920,076$ & 0.18 & 311,501 & 18,089 & 673,116 \\
\hline$(+/-) \mathrm{SF}-$ Net Interest & $-34,297,934$ & -0.25 & $-428,724$ & $-554,459$ & $1,045,536$ \\
\hline $\begin{array}{c}(+/-) \mathrm{W}-\text { Revaluations and } \\
\text { Devaluations }\end{array}$ & $-18,902,430$ & -0.14 & $-236,280$ & - & $1,464,913$ \\
\hline $\begin{array}{c}(+/-) X-\text { Extraordinary } \\
\text { revenues and costs }\end{array}$ & $2,732,257$ & 0.02 & 34,153 & - & 357,689 \\
\hline $\begin{array}{c}(+/-) \text { ПаТ—Profit before } \\
\text { taxes }\end{array}$ & $83,034,038$ & 0.6 & $1,037,925$ & 331,879 & $3,476,878$ \\
\hline$(-) \mathrm{T}$-Income taxes & $23,976,913$ & 0.17 & 299,711 & 177,565 & 360,561 \\
\hline$(+/-) \Pi p \mathrm{p}-$ Profit after taxes & $59,057,125$ & 0.43 & 738,214 & 156,856 & $3,279,343$ \\
\hline
\end{tabular}

The analysis by ratios and margins allows one to deepen some aspects of the AAS, as shown in Table 6. ROE data confirmed the low profitability highlighted by the analysis of the income statement; in fact, the average ROE was $1.50 \%$ (median value $2.15 \%$ ). The return on equity capital therefore appeared decidedly modest, in many cases lower than both the risk-free rate represented by Italian government bonds (with yields in the decade aligned between 2 and 5 percentage points) and in the same way lower than the market risk premiums for Italy (aligned between 5 and 7 percentage points in the decade covered by the historical series, between 2008 and 2017); in addition, the analysis of the ROA showed modest data, with an average profitability of $1.05 \%$ and a median of $1.80 \%$. There was great variability of the ROA result in the sample, as evidenced by the standard deviation of the sample, which was equal to $3.95 \%$, and in 69 out of 80 observations the ROA was greater than zero. The average cost of debt (ROD) was $1.36 \%$, with a median of $1.01 \%$. ROD variability was low, with a sample standard deviation of $0.26 \%$. Many companies in the sector, therefore, expressed a positive profitability, albeit on very modest values, using very little financial debt, which, given the low profitability generated by management, would entirely erode profit margins; in fact, only in 33 out of 80 cases was the ROA greater than $2 \%$ and only in 2 out of 80 cases was it greater than 5\%. Finally, in 65 out of 80 observations, the ROA was greater than the ROD, allowing financing capital to be acquired from the banking system at a lower cost than the operating profitability of the invested capital and, therefore, having convenience in financial leverage. 
Table 6. Financial ratios and margins (FRM) analysis, 80 observation data points (8 firms for 10 financial years), descriptive statistics.

\begin{tabular}{cccc}
\hline Financial Ratio ID & Mean & Median & St. Dev. Sample \\
\hline ROE-return on equity & $1.50 \%$ & $2.17 \%$ & $23.15 \%$ \\
ROA-return on asset & $1.05 \%$ & $1.80 \%$ & $6.95 \%$ \\
ROD-return on debts & $1.36 \%$ & $1.01 \%$ & $0.26 \%$ \\
DER-debt equity ratio & 13.97 & 2.81 & 4.13 \\
CR-current ratio & 3.67 & 1.35 & 1.88 \\
AR_DAYS & 68 & 72 & 3 \\
AP_DAYS & 30 & 28 & 1 \\
INV_DAYS & 21 & 19 & 1 \\
NWC_DAYS & 60 & 63 & 2 \\
\hline
\end{tabular}

The level of corporate debt was not high; in fact, even if the average DER was 13.97, the median DER was 2.81; however, in order to understand the index, it should be considered that the median capital structure in the companies in the sample was structured for 24.7 million in financial debt and 19.5 million euros in operating debt per company, while the median equity capital was 27.0 million euros. These data highlight how the level of debt was modest, if only the financial debt in relation to the risk capital was considered, and then the scarce use of financial debt by the companies in the sector was therefore confirmed. The CR expired as investments in short-term assets were greater than in short-term liabilities; in fact, the average value of $C R$ was 3.67, while the median value was 1.35; it is interesting to note that in 79 observations out of 80 , the $C R$ was greater than zero.

The cycle data of the duration of the working capital cycle were also relevant for the purpose of defining forms of intervention, private and public, in the sector; in fact, the average duration of the accounts receivable of the companies in the sector was 68 days (72 days the median data), against an average duration of the extension from suppliers (accounts payable) of 30 days ( 28 the median data) and a transit to the warehouse in 21 days (19 the median data). It therefore emerges that the NWC_DAYS (cash conversion cycle given by AR_DAYS + INV_DAYS-AP_DAYS) was 60 days on average (63 days the median figure). In 74 observations out of 80 , NWC had a positive day value, and this expresses that the firms in the sector largely needed financing to cope with short-term investments.

\section{Discussion}

The usefulness of the FRM analysis was the subject of several studies in the agri-food sector highlighting how the analysis of accounting data for the purpose of calculating the ratios is useful for measuring the risk of agricultural and agri-food firms, and their sustainability over time [66]. Other recent studies, for the case of Italian agriculture, have highlighted the importance of the evaluation of financial sustainability in the analysis of public intervention policies [67]. Moreover, the effect on social well-being of a public intervention in support of agri-food chains was analyzed by a pilot study that dealt with farm economic sustainability [68]. However, the obligation to indicate the social effects of business activities is still lacking in the regulations, for example with data from the social balance sheet. For this reason, there are no mandatory data that measure the effect of social and environmental sustainability of the business, but only economic sustainability; this is true at least for the data that must be made public by law [69].

A first topic of analysis of economic sustainability concerns capital investments. The companies in the sample are characterized by having an average invested capital (71.2 million euros) lower than the average turnover (173.1 million euros). The analysis has highlighted that investments in fixed assets are fully financed with risk capital, and this contributes to the stability of the financial structure of the sources of capital. The firms are characterized by investments concentrated in active working capital, in particular in accounts receivable; $47.97 \%$ of the assets invested by the sample companies are trade receivables. Trade payables represent $21.17 \%$ of the sources of financing. It emerges 
that $26.80 \%$ of the invested assets, consisting of trade receivables, must be financed with financial debt or risk capital. The data of the CR ratio confirm that the companies in the sample absorb liquidity in the working capital cycle, in particular in the collection cycle of trade receivables, and require consequent short-term financial hedges and tools to control customer solvency. The analysis of the companies in the sample therefore shows that the NWC cycle absorbs significant sources of funding. This result confirms what has emerged in other studies also related to the agri-food sector [70] and agri-food chains [71]; however, there are no studies on this issue for the swine slaughter sector, and therefore the research can be deepened, not only on data from Italian firms. The issue of financial constraints is particularly relevant in the growth phase of companies [72], in cases of mergers and acquisitions [73], and in the case of cooperative firms [74]. This research result highlights the difficulty of the companies in the sample to use bank loans to support the operating cycle, in particular for the advancement of working capital. This certainly represents a possible area of intervention for financial intermediaries, banks, and factoring companies, in this case assisted by guarantee consortia for the supply of collateral to credit risk, to assist companies in the sector, particularly for firms of a smaller size not considered in the study and expected to have a more difficult access to credit, both in terms of cost and rationing of the credit granted.

A second topic of economic sustainability concerns the comparison between profitability and the cost of financial debt. The regulation of access to credit requires firms to be able to pay the cost of debt and repay loans; this must be done by guaranteeing investors an adequate remuneration for risk. The study confirms that the companies in the sample meet this condition; in fact, the analysis of profitability (ROA) compared with the cost of financial debt (ROD) shows that companies can use financial leverage (ROA greater than ROD in most of the observations), and the result confirms what emerged in other studies also related to the agri-food sector $[75,76]$; this result allows one to acquire financing capital from the banking system at a lower cost than the operating profitability of the invested capital and, therefore, to have convenience in financial leverage. These data can be developed with further investigations, which the AASs do not allow, thus considering the cost of the individual lines of financing and the financial level of average debt during the year; these analyzes require confidential company data, which are not currently available in research. The analysis confirms what emerged in a recent research [77], which indicates the need to have income margins available to pay the cost of debt; in the absence of this condition, it appears impossible to satisfy the conditions for access to bank credit that are given by the Basel III rules [78]. However, due to the low profitability expressed by operations, it is difficult to finance with onerous debt capital, such as forms of bank financing, the advancement of trade receivables; the financing of the monetary conversion cycle with risk capital does not solve the problem, and in fact this form of financing in terms of risk capital requires a minimum expected return (cost of equity) generally higher than the cost of financial debt. The difficulty of the companies analyzed in the sample to access the stock exchange market for financing in terms of equity is therefore evident. Furthermore, the high incidence of raw material costs suggests forms of supply chain integration in order to reduce the risk of business default to be implemented also with forms of public intervention to support the supply chain policies. This research line could be conducted by analyzing differences in the performance between cooperative and non-cooperative firms, both in terms of profit margins and sources of funding with the analysis of its cost; this line of research takes up seminal work that shows the performance of cooperative and non-cooperative enterprises for the US food industries [79] then developed in recent years $[80,81]$.

The analysis of the income statement of the companies in the sample exposes indications of economic sustainability. The cost of raw materials is $85.25 \%$ of the turnover in the analyzed sample; the data show that the companies in the sector have risks associated with the market price of raw materials. The industry appears at this time compressed between the high prices of raw materials and the requests for containment of sales prices to support 
consumption [82]. However, it is evident that the profitability of the sector, at least on the basis of the data analyzed, is not able to attract investments in equity capital, which then have an adequate remuneration for the level of risk assumed, given the average size of the company, the exposure to customers, and the high dependence on the purchase costs of raw materials; the high incidence of raw materials on the profitability of the companies in the sample has a negative effect on economic sustainability. Forms of stabilization of the food supply chain can be applied through price fixing mechanisms through long-term contractual relationships or applying forms of vertical integration along the supply chain or with forms of cooperative collaboration [83]. In this way, it will be possible to suggest improvement interventions also in this segment of companies that often has greater difficulties in accessing the capital market and which play a social role, in particular for Denomination of Origin products, particularly in rural and marginal production areas [84].

\section{Conclusions}

The major research findings are as follows: (1) the companies involved in the sample have adequate capitalization in terms of risk capital; (2) the greatest absorption of capital is in the cycle of working capital; (3) corporate profitability is low, even if it is higher than the cost of debt. There is therefore economic sustainability in terms of capital structure, but the companies in the sample are lacking in terms of profitability compared to the cost of debt and for the absorption of resources in the working capital cycle.

The results of the research are therefore applicable at the current level of analysis, both by the managers of the companies in the sector to better define the financial structure of the capital and investigate the modest profitability found, both by public operators and, together with the financial institutions, will be able to evaluate forms of financing in the case assisted by public guarantee consortia to finance the cycle of working capital in the sector to improve the sustainability of the management cycle.

Author Contributions: G.B., G.F. and E.M. wrote jointly the section titled "Introduction"; P.C. wrote the section titled "The Sample of Companies Operating in the Pig Slaughtering Sector"; M.I. wrote the sections titled "Annual Account Statement (AAS) Analysis", "Analysis of the Management of the Companies in the Sample by Applying Financial Ratios and Margins (FRM) Analysis" and "Discussion". The section "Financial Ratios and Margins (FRM) Analysis" was written jointly by M.I. and P.C. with equal contributions from the authors. The section "Conclusions" was written jointly by M.I. and G.B. with equal contributions from the authors. M.I. oversaw the methodology and the general revision of the research. All authors have read and agreed to the published version of the manuscript.

Funding: This research received no external funding.

Institutional Review Board Statement: Not applicable.

Informed Consent Statement: Not applicable.

Data Availability Statement: The data presented in this study are available upon request from the corresponding author.

Acknowledgments: The authors would like to thank analisiaziendale.it for IT assistance.

Conflicts of Interest: The authors declare no conflict of interest.

\section{References}

1. Van Ittersum, K.; Meulenberg, M.T.G.; van Trijp, H.C.M.; Candel, M.J.J.M. Consumers' appreciation of regional certification labels: A pan-European study. J. Agric. Econ. 2007, 58, 1-23. [CrossRef]

2. Bonadonna, A.; Aceto, P.; Peira, G.; Varese, E. Hypothesis for relaunch of the pig farming sector in piedmont: Medium/heavy pigmeat as the raw material in the production of cooked ham. Qual. Access Success 2013, 14, 114-118.

3. Tudisca, S.; Di Trapani, A.M.; Sgroi, F.; Testa, R. Economic evaluation of PDO introduction in Sicilian orange farms. Qual. Access Success 2014, 15, 99-103.

4. Garavaglia, C.; Mariani, P. How Much Do Consumers Value Protected Designation of Origin Certifications? Estimates of willingness to Pay for PDO Dry-Cured Ham in Italy. Agribusiness 2017, 33, 403-423. [CrossRef] 
5. Sgroi, F.; Mineo, A.M.; Donia, E.; Piampiano, S. Consumer preferences for food products. Qual. Access Success 2018, 19, 123-130.

6. Prestamburgo, S.; Sgroi, F. Agro-food markets' functional efficiency, products' quality and information's role. Qual. Access Success 2018, 19, 145-149.

7. Frascarelli, A. La politica dei mercati agricoli dell'Ue per il periodo 2014-2020: Un'analisi degli strumenti. Agriregionieuropa 2016, 12, 9-14.

8. Branciari, R. La macellazione, la trasformazione e la sanità degli alimenti: La normativa e gli adempimenti di legge. Available online: https:/ / www.cesarweb.com/wp-content/uploads/2017/05/PAC_INFORMA_PUB_02.pdf (accessed on 2 May 2021).

9. De Luca, A.I.; Molari, G.; Seddaiu, G.; Toscano, A.; Bombino, G.; Ledda, L.; Milani, M.; Vittuari, M. Multidisciplinary and innovative methodologies for sustainable management in agricultural systems. Environ. Eng. Manag. J. 2015, 4, 1571-1581. [CrossRef]

10. ASSICA. Rapporto annuale 2018. Available online: https://www.assica.it/it/pubblicazioni/rapporto-annuale.php (accessed on 5 April 2021).

11. Faostat Data. Available online: http://www.fao.org/faostat/en/\#data/QL (accessed on 24 April 2021).

12. ASSICA. Rapporto annuale 2019. Available online: https://www.assica.it/it/pubblicazioni/rapporto-annuale.php (accessed on 5 April 2021).

13. Bosi, P.; Russo, V. The production of the heavy pig for high quality processed products. J. Anim. Sci. 2004, 3, 309-321. [CrossRef]

14. ISTAT data pig sector in Italy. Available online: http:/ / dati.istat.it/Index.aspx?DataSetCode=DCSP_CONSISTENZE (accessed on 20 March 2021).

15. Stillitano, T.; Spada, E.; Iofrida, N.; Falcone, G.; De Luca, A.I. Sustainable Agri-Food Processes and Circular Economy Pathways in a Life Cycle Perspective: State of the Art of Applicative Research. Sustainability 2021, 13, 2472. [CrossRef]

16. ISTAT Data Slaughterhouse Sector in Italy. Available online: http:/ / dati.istat.it/Index.aspx?DataSetCode=DCSP_MACELLAZIONI (accessed on 20 March 2021).

17. Iotti, M.; Bonazzi, G. Analysis of the Risk of Bankruptcy of Tomato Processing Companies Operating in the Inter-Regional Interprofessional Organization "OI Pomodoro da Industria Nord Italia". Sustainability 2018, 10, 947. [CrossRef]

18. Grossi, G.; Soverchia, M. European commission adoption of IPSAS to reform financial reporting. Abacus 2011, 4, 525-552. [CrossRef]

19. Dechow, P.M. Accounting Earnings and Cash Flow as Measures of Firm Performance, the Role of Accounting Accruals. J. Account. Econ. 1994, 18, 3-42. [CrossRef]

20. Shulman, J.; Cox, R. An Integrative Approach to Working Capital Management. J. Cash Manag. 2009, 5, 32-38.

21. Carroll, C.; Griffith, J.M. Free Cash Flow, Leverage, and Investment Opportunities. Q. J. Bus. Econ. 2001, 3, $27-51$.

22. Boisjoly, R.P.; Izzo, S. The Cash Flow Implications of Managing Working Capital and Capital Investment. J. Bus. Econ. Stud. 2009, 15, 98-109.

23. Love, I.; Preve, L.; Sarria-Allende, V. Trade Credit and Bank Credit: Evidence from Recent Financial Crisis. J. Financ. Econ. 2007, 73, 453-469. [CrossRef]

24. Weinraub, H.J.; Visscher, S. Industry Practice Relating to Aggressive and Conservative Working Capital Policies. J. Financ. Strateg. Decis. 1998, 9, 21-37.

25. Kargar, J.; Blumenthal, R.A. Leverage Impact of Working Capital in Small Businesses. TMA J. 1994, 14, 46-53.

26. Grablowsky, B.J. Financial Management of Inventory. J. Small Bus. Manag. 1984, 22, 59-65.

27. Hill, M.D.; Kelly, W.G.; Highfield, M.J. Net Operating Working Capital Behavior: A First Look. Financ. Manag. 2010, 2, 783-805. [CrossRef]

28. Deloof, D. Does Working Capital Management Affect Profitability of Belgian Firms? J. Bus. Financ. Account. 2003, 30, 573-587. [CrossRef]

29. Banos-Caballero, S.; Garcia-Teruel, P.J.; Martinez-Solano, P. How does working capital management affect the profitability of Spanish SMEs? Small Bus. Econ. 2012, 39, 517-529. [CrossRef]

30. Gray, S.; Mirkovic, A.; Ragunathan, V. The Determinants of Credit Ratings: Australian Evidence. Aust. J. Manag. 2006, 31, 333-354. [CrossRef]

31. Molina, C.; Preeve, L. Trade Receivable Policy of Distressed Firms and its Effects on the Cost of Financial Distress. Financ. Manag. 2009, 38, 663-686. [CrossRef]

32. Berryman, J. Small Business Failure and Bankruptcy: A Survey of the Literature. Eur. Small Bus. J. 1983, 1, 47-59. [CrossRef]

33. Boisjoly, R.P.; Conine, T.E.; McDonald, M.B. Working capital management: Financial and valuation impacts. J. Bus. Res. 2020, 108, 1-8. [CrossRef]

34. Svabova, L.; Michalkova, L.; Durica, M.; Nica, E. Business Failure Prediction for Slovak Small and Medium-Sized Companies. Sustainability 2020, 12, 4572. [CrossRef]

35. Cepec, J.; Grajzl, P. Management turnover, ownership change, and post-bankruptcy failure of small businesses. Small Bus. Econ. 2021, 57, 555-581. [CrossRef]

36. Afrifa, G.A. Net working capital, cash flow and performance of UK SMEs. Rev. Account. Financ. 2016, 15, 21-44. [CrossRef]

37. Zabolotnyy, S.; Sipilainen, T. A comparison of strategies for working capital management of listed food companies from Northern Europe. Agric. Food Sci. 2020, 29, 239-249. [CrossRef] 
38. Wang, Z.; Akbar, M.; Akbar, A. The Interplay between Working Capital Management and a Firm's Financial Performance across the Corporate Life Cycle. Sustainability 2020, 12, 1661. [CrossRef]

39. Mabandla, N.Z.; Makoni, P.L. Working capital management and financial performance: Evidence from listed food and beverage companies in South Africa. Acad. Account. Financ. Stud. 2019, 23, 2.

40. Rey-Ares, L.; Fernandez-Lopez, S.; Rodeiro-Pazos, D. Marine Impact of working capital management on profitability for Spanish fish canning companies. Mar. Policy 2021, 130, 104583. [CrossRef]

41. Fernández-López, S.; Rodeiro-Pazos, D.; Rey-Ares, L. Effects of working capital management on firms' profitability: Evidence from cheese-producing companies. Agribusiness 2020, 36, 770-791. [CrossRef]

42. Gollo, V.; Kruger, S.D.; Mazzioni, S.; Da Cunha, P.R. Comparative analysis of the economic and financial results between pig and dairy production. Custos e Agronegocio 2015, 11, 93-113.

43. Beaver, W.H. Financial Ratios as Predictors of Failure. J. Account. Res. 1966, 4, 71-111. [CrossRef]

44. Altman, E.I. Financial Ratios, Discriminant Analysis and Prediction of Corporate Bankruptcy. J. Financ. 1968, $234,589-609$. [CrossRef]

45. Johnson, R.B.; Haegn, A.R. Agricultural Loan Evaluation with Discriminant Analysis. J. Agric. Appl. Econ. 1973, 5, 57-62. [CrossRef]

46. Ohlson, J.A. Financial Ratios and the Probabilistic Prediction of Bankruptcy. J. Account. Res. 1980, 18, 109-131. [CrossRef]

47. Hillegeist, S.A.; Keating, E.K.; Cram, D.P.; Lundstedt, K.G. Assessing the probability of bankruptcy. Rev. Account. Stud. 2004, 9, 5-34. [CrossRef]

48. Beaver, W.; McNichols, M.; Rhie, J.W. Have financial statements become less informative? Evidence from the ability of financial ratios to predict bankruptcy. Rev. Account. Stud. 2005, 10, 93-122. [CrossRef]

49. Beaver, W.; Correia, M.; McNichols, M.F. Do differences in financial reporting attributes impair the predictive ability of financial ratios for bankruptcy? Rev. Account. Stud. 2012, 17, 969-1010. [CrossRef]

50. Soliman, M.T. The use of DuPont analysis by market participants. Account. Rev. 2008, 83, 823-853. [CrossRef]

51. Bauman, M.P. Forecasting operating profitability with DuPont analysis Further evidence. Rev. Account. Financ. 2014, 13, 191-205. [CrossRef]

52. Jin, Y. DuPont Analysis, Earnings Persistence, and Return on Equity: Evidence from Mandatory IFRS Adoption in Canada. Account. Perspect. 2017, 16, 205-235. [CrossRef]

53. Barbier, P.J.A. Financial return on equity (FROE): A new extended dupont approach. Acad. Account. Financ. Stud. J. 2020, $24,2$.

54. Capitanio, F.; Sgroi, F.; Adinolfi, F. Misura delle performance finanziarie e patrimoniali delle aziende agricole: Proposta operativa per un nuovo modello di rating per le aziende agricole. Rivista di Economia Agraria 2012, 67, 27-44.

55. Cupo, P.; Di Domenico, M. I fattori che influiscono sul merito creditizio delle aziende agricole: Un'applicazione in Campania. Rivista di Economia Agraria 2012, 67, 45-67. [CrossRef]

56. Lazo, D.; Calabrese, R.; Bravo, C. The effects of customer segmentation, borrower behaviors and analytical methods on the performance of credit scoring models in the agribusiness sector. J. Credit. Risk 2020, 16, 119-156.

57. Zira, S.; Rydhmer, L.; Ivarsson, E.; Hoffmann, R.; Roos, E. A life cycle sustainability assessment of organic and conventional pork supply chains in Sweden. Sustain. Prod. Consum. 2021, 28, 21-38. [CrossRef]

58. Valente, C.; Møller, H.; Johnsen, F.M.; Saxegård, S.; Rasten Brunsdon, E.; Alvseike, O.A. Life cycle sustainability assessment of a novel slaughter concept. J. Clean. Prod. 2020, 272, 122651. [CrossRef]

59. Banos-Caballero, S.; Garcia-Teruel, P.J.; Martinez-Solano, P. Financing of working capital requirement, financial flexibility and SME performance. J. Bus. Econ. Manag. 2016, 17, 1189-1204. [CrossRef]

60. Banos-Caballero, S.; Garcia-Teruel, P.J.; Martinez-Solano, P. Net operating working capital and firm value: A cross-country analysis. BRQ Bus. Res. Q. 2021, 23, 234-251. [CrossRef]

61. Aktas, N.; Croci, E. Petmezas, D. Is working capital management value-enhancing? Evidence from firm performance and investments. J. Corp. Financ. 2015, 30, 98-113. [CrossRef]

62. Iotti, M.; Bonazzi, G. Application of ICRs with a net financial position (NFP) repayment approach in the Parma PDO ham sector. J. Food Agric. Environ. 2015, 13, 109-114.

63. Boyd, S.; Boland, M.; Dhuyvetter, K.; Barton, D. Determinants of return on equity in US local farm supply and grain marketing cooperatives. J. Agric. Appl. Econ. 2007, 39, 201-210. [CrossRef]

64. Mishra, A.K.; Harris, J.M.; Erickson, K.W.; Hallahan, C.; Detre, J.D. Drivers of agricultural profitability in the USA: An application of the Du Pont expansion method. Agric. Financ. Rev. 2012, 72, 325-340. [CrossRef]

65. Dono, G.; Buttinelli, R.; Cortignani, R. Financial sustainability in Italian farms: An analysis of the FADN sample. Agric. Financ. Rev. 2021. [CrossRef]

66. Argiles, J.M.; Slof, E.J. The use of financial accounting information and firm performance: An empirical quantification for farms. Account. Bus. Res. 2003, 33, 251-264. [CrossRef]

67. De Luca, A.; Falcone, G.; Iofrida, N.; Stillitano, T.; Strano, A.; Gulisano, G. Life cycle methodologies to improve agri-food systems. Sustainability 2015, 1, 135-150. [CrossRef]

68. O'Donoghue, C.; Devisme, S.; Ryan, M.; Conneely, R.; Gillespie, P.; Vrolijk, H. Farm economic sustainability in the European Union: A pilot study. Stud. Agric. Econ. 2016, 118, 163-171. [CrossRef] 
69. Iofrida, N.; De Luca, A.I.; Strano, A.; Gulisano, G. Can social research paradigms justify the diversity of approaches to social life cycle assessment? Int. J. Life Cycle Assess 2018, 23, 464-480. [CrossRef]

70. Golas, Z. Impact of working capital management on business profitability: Evidence from the polish dairy industry. Agric. Econ. 2020, 66, 278-285.

71. Hofmann, E.; Kotzab, H. A supply chain-oriented approach of working capital management. J. Bus. Logist. 2010, 2, 305-330. [CrossRef]

72. Escalante, C.L.; Turvey, C.G.; Barry, P.J. Farm business decisions and the sustainable growth challenge paradigm. Agric. Financ. Rev. 2009, 69, 228-247. [CrossRef]

73. Nguyen, S.V.; Ollinger, M. Mergers and acquisitions, employment, wages, and plant closures in the U.S. meat product industries Agribusiness 2009, 25, 70-89. [CrossRef]

74. Piccoli, P.; Bianchini, N., Jr.; Coser, J.; Moreira, V.R. Short-term financial sustainability of agricultural cooperatives. Agric. Financ. Rev. 2020, 81, 444-457. [CrossRef]

75. Doorasamy, M. Using DuPont analysis to assess the financial performance of the top 3 JSE listed companies in the food industry. Invest. Manag. Financ. Innov. 2016, 13, 29-44. [CrossRef]

76. Santosa, P.W. The effect of financial performance and innovation on leverage: Evidence from Indonesian food and beverage sector. Organ. Mark. Emerg. Econ. 2020, 11, 367-388.

77. Gama, A.P.M.; Geraldes, H.S.A. Credit risk assessment and the impact of the New Basel Capital Accord on small and mediumsized enterprises: An empirical analysis. Manag. Res. Rev. 2012, 35, 727-749. [CrossRef]

78. Kim, K.N.; Katchova, A.L. Impact of the Basel III Bank Regulation on US Agricultural Lending. Agric. Financ. Rev. 2020, 80, 321-337. [CrossRef]

79. Lerman, Z.; Parliament, C. Comparative performance of cooperatives and investor-owned firms in US food Industries. Agribusiness 1990, 6, 527-540. [CrossRef]

80. Singh, K.; Misra, M.; Kumar, M.; Tiwari, V. A study on the determinants of financial performance of U.S. agricultural cooperatives. J. Bus. Econ. Manag. 2019, 4, 633-647. [CrossRef]

81. Grashuis, J. A Quantile regression analysis of farmer cooperative performance. Agric. Financ. Rev. 2018, 78, 65-821. [CrossRef]

82. Laureati, M.; Buratti, S.; Giovanelli, G.; Corazzin, M.; Lo Fiego, D.P.; Pagliarini, E. Characterization and differentiation of Italian Parma, San Daniele and Toscano dry-cured hams: A multi-disciplinary approach. Meat Sci. 2014, 96, 288-294. [CrossRef]

83. Fejes, J.; Sarudi, C.; Széles, G. Work organisation in the production of slaughter pigs on Hungarian and Japanese pig farms. Acta Agrar. Kaposváriensis 1999, 3, 315-324.

84. Malorgio, G.; Marangon, F. The challenge of sustainability. Agric. Food Econ. 2021, 9, 1-4. [CrossRef] 